\section{Tubal ligation regret and related risk factors: findings from a case-control study in Pernambuco State, Brazil}

\author{
Fatores de risco para o arrependimento da \\ laqueadura tubária: resultados de um estudo de \\ caso-controle em Pernambuco, Brasil
}

\author{
${ }^{1}$ Departamento de Medicina \\ Social, Universidade Federal \\ de Pernambuco, Recife \\ Brasil. \\ 2 Centro Integrado de \\ Saúde Amaury de Medeiros, \\ Universidade de Pernambuco, \\ Recife, Brasil. \\ Correspondence \\ A. B. Ludermir \\ Departamento de Medicina \\ Social, Universidade Federal \\ de Pernambuco. \\ Av. Conselheiro Rosa e Silva \\ 377 , apto. 1601, Recife, $P E$ \\ 52020-220, Brasil. \\ abl@ufpe.br
}

\begin{abstract}
A case-control study was carried out at a public teaching hospital in Recife, Pernambuco State, Brazil in 1997 to investigate risk factors among women who feel regret after undergoing sterilization through tubal ligation. The study compared sterilized women who had requested or undergone a tubal reversal with women who were also sterilized but had not undergone this surgery, nor had requested to do so. Women showing a significantly greater probability of regret were those sterilized at a young age, those who had not themselves made the decision to undergo surgery, those for whom the sterilization was carried out up to the 45th day after childbirth and those who had acquired knowledge about contraceptive methods after the tubal ligation procedure. Having had a deceased child, a partner with no children prior to the current union or a change of partner after the tubal sterilization procedure were also associated to the request for or submission to tubal sterilization reversal. It is necessary to assess women's psycho-socio-demographic profiles, their reasons for requesting tubal ligation and to advise the patient about family planning in order to reduce rates of post-sterilization regret.
\end{abstract}

Sterilization Reversal; Tubal Sterilization; Family Planning

\author{
Ana Bernarda Ludermir 1 \\ Kátia Maria de Melo Machado 2 \\ Aurélio Molina da Costa 2 \\ Sandra Valongueiro Alves 1 \\ Thália Velho Barreto de Araújo 1
}

\section{Introduction}

Tubal ligation (or sterilization) is the most common form of contraception in Brazil, and the country currently has one of the highest female sterilization rates in the world 1,2. Although illegal in Brazil before 1997, tubal sterilization has been a common practice in the private sector and public health system for many years 3 . A number of authors 3,4 have reported rising rates of unnecessary cesarean sections as an opportunity to perform tubal ligation. A national study carried out by BEMFAM (Bem Estar Familiar no Brasil) in Brazil in 1996 revealed that approximately $40 \%$ of women between the ages of 15 and 49 who had a partner and used some form of contraception were sterilized 5 . The age at which women seek sterilization has dropped and a large number of surgeries are carried out before the patient has reached the age of 25 5,6. The lack of information on the part of women, the scarcity of contraceptive methods in the public sector, the interventionist power of doctors regarding the bodies and health of women, and the lack of technical training among health professionals in dealing with family planning are factors that influence a woman's ability to make autonomous decisions about contraceptive methods 7 .

An increasing number of women have shown regret after undergoing tubal ligation. Regret rates in Brazil vary from $10 \%$ to $20 \%$ of 
all sterilized women $8,9,10,11,12,13$. Although the term regret is frequently associated with feeling of sadness, sorrow, pain, affliction, hurt, dissatisfaction and anxiety, some authors have considered "clearly regretful" only the women who manifest their desire and intent to undergo surgery for tubal reversal 1 . The request for tubal reversal is a complex phenomenon. The literature has shown an association between regret after tubal sterilization and the death of children, a new marriage, changes in socioeconomic status, whether the decision for surgery came from the woman herself, the woman's age and number of children at the time of tubal ligation, the lack of information about surgical sterilization (including the issue of irreversibility), and the time the surgery is performed in relation to delivery $1,13,14,15$.

This study investigates risk factors for regret following tubal ligation at a public teaching hospital in Recife, Pernambuco State, Northeast Brazil.

\section{Methods}

\section{Study area}

The Amaury de Medeiros Integrated Health Center (CISAM) is a teaching hospital at the University of Pernambuco and is part of Brazil's public health system (SUS - Unified National Health System). It consists of a maternity hospital and 48 consultation rooms for basic and specialized health care, receiving mainly low income patients. The fertility clinic attends approximately 60 women per week.

\section{Definition and selection of cases and controls}

An exploratory case-control study was carried out in 1997. The group of cases consisted of all sterilized women attending the fertility clinic at CISAM who requested or had undergone tubal reversal in 1997. The control group also consisted of sterilized women who attended the gynecology clinic at CISAM, but who had not requested, undergone or expressed intent to request this surgery. Thus, the inclusion criteria for cases were: having been sterilized and having come to the fertility clinic at CISAM to request surgical reversal of tubal ligation in 1997. The inclusion criteria for controls were: prior sterilization; attendance at one of the CISAM gynecology clinics in 1997, awareness of the fertility clinic at CISAM, not having undergone or expressed the intent to request surgical tubal reversal.

\section{Data collection}

Data collection was carried out through interviews by one of the authors. All cases were identified in the surgery registry book. 200 women who requested tubal reversal were interviewed in the waiting room of the fertility clinic. Those who had already undergone tubal reversal in 1997 were contacted by mail and interviewed by telephone. The control group was recruited in the same waiting room as the cases (CISAM Gynecology Clinic) and during the same period. There were no refusals to participate. A structured, precoded questionnaire was used to obtain information on age, number of years of schooling, paid employment, reasons for requesting or undergoing tubal reversal, characteristics of women in relation to tubal ligation and changes in family structure. Full details of the data collection are reported elsewhere 16 .

\section{Definition of variables}

Age of the woman in years at the time of the interview (20-29; 30-39 and 40-49), education, assessed in terms of years of schooling (0-10 and $\geq 11$ ), and paid employment (yes and no) were investigated.

The main reasons that led to women requesting or undergoing tubal reversal were categorized as: the desire to have children with a new partner; wanting to have more children regardless of the partner's wish; the death of a child or children; and regret following tubal sterilization.

The characteristics of women in relation to tubal ligation were assessed with regard to their age at the time of tubal ligation; the tubal ligation decision-maker; the time at which the surgery took place, in relation to the last delivery; and information on irreversibility provided to the woman by health professionals prior to surgery. These characteristics were classified as follows:

- Age at the time of tubal ligatioin: woman's age in complete years at the time of tubal ligation, categorized as: $13-19 ; 20-24 ; 25-29$ and $\geq 30$;

- Tubal ligation decision-maker, defined as the person who most contributed to the decision, was categorized as: woman and other (husband/ partner; mother; mother-in-law; friend; doctor; boss or supervisor);

- Time when tubal ligation was performed in relation to the last delivery, categorized as: transcaesarean up to 45 days after childbirth and more than 45 days after-childbirth;

- Information on tubal ligation irreversibility, categorized as whether or not provided to the woman by health professionals at the time of the tubal ligation request. 
Knowledge of contraceptive methods obtained after tubal ligation was assessed by the acquisition of knowledge on contraceptive methods between the time that the tubal ligation was performed and the request for reversal.

Changes in family structure were evaluated based on the following variables: death of one or more children, partner with one or more children from a previous union, and change of partner.

- Death of children was defined as the death of either the woman's child or that of her partner from the time of tubal ligation to the time of the interview and was categorized as yes or no;

- Partner with children from a previous union referred to whether the partner had one or more children prior to the current union;

- Partner change referred to whether the current partner was the same at the time of tubal ligation.

\section{Data analysis}

Unconditional logistic regression was used to estimate the associations between risk factors under study and the request for or undergoing of tubal reversal. Effect modification was evaluated by a likelihood ratio test (LRT) for the significance of the terms of interaction 17. Confounding was assessed using a stepwise strategy. First, the univariate association of age, years of schooling, paid employment, tubal ligation characteristics and changes in family structure with the outcome were estimated. Variables whose association was significant at $\mathrm{p} \leq 0.10$ were included in a multivariate model. Those variables with $\mathrm{p}>0.10$ were dropped from the final model. Odds ratios (OR) and 95\% confidence intervals $(95 \% \mathrm{CI})$ were calculated to estimate the magnitude of the associations. This analysis was carried out with 577 women (301 cases and 276 controls) who had complete data on all variables included in the model.

The study complied with the ethical principles governing research involving human beings, and received prior approval from a research ethics committee. Using free and informed consent, approval was sought from the women, who were informed of the nature of the study and its objectives, methods, and potential benefits. The privacy and confidentiality of the information were guaranteed.

\section{Results}

Table 1 presents the distribution of demographic and socioeconomic variables among cases and controls. Age and paid employment show statistically significant associations with requests for or undergoing of tubal reversal.

Among those women who requested or had undergone tubal reversal, $88.5 \%$ reported that the main reason was to have children with a new partner.

Table 2 displays the distribution of tubal ligation characteristics between the cases and

Table 1

Age, schooling and paid employment among women who did or did not request or undergo tubal reversal at a public teaching hospital. Recife, Pernambuco State, Brazil, 1997.

\begin{tabular}{|c|c|c|c|c|c|}
\hline \multirow[t]{2}{*}{ Variables } & \multicolumn{2}{|c|}{ Tubal reversal } & \multicolumn{2}{|c|}{ No tubal reversal } & \multirow[t]{2}{*}{ OR $(95 \% \mathrm{Cl})$} \\
\hline & $\mathbf{n}$ & $\%$ & $\mathbf{n}$ & $\%$ & \\
\hline \multicolumn{6}{|c|}{ Age at interview (years) } \\
\hline $20-29$ & 85 & 28.4 & 61 & 22.1 & $5.10(2.8-9.3)$ \\
\hline $30-39$ & 197 & 65.4 & 146 & 52.9 & $4.90(2.8-8.5)$ \\
\hline $40-49$ & 19 & 6.2 & 69 & 25.0 & 1.00 \\
\hline $\mathrm{p}$ value & & & & & $<0.0001$ \\
\hline \multicolumn{6}{|c|}{ Schooling (years) } \\
\hline $0-10$ & 113 & 37.5 & 109 & 39.5 & $0.92(0.7-1.3)$ \\
\hline$\geq 11$ & 188 & 62.5 & 167 & 60.5 & 1.00 \\
\hline$p$ value & & & & & 0.63 \\
\hline \multicolumn{6}{|c|}{ Woman in paid employment } \\
\hline Yes & 123 & 40.9 & 91 & 33.0 & 1.00 \\
\hline No & 178 & 59.1 & 185 & 67.0 & $0.71(0.5-1.0)$ \\
\hline$p$ value & & & & & 0.05 \\
\hline
\end{tabular}


controls. In the univariate analysis, statistically significant associations were found between the request for or submission to tubal reversal and having undergone tubal ligation prior to the age of 30; where the decision was not made by the subject herself; where the sterilization was carried out up to 45 days after childbirth including the trans-caesarean period; where patients had received no information on the irreversibility of the surgery.

Those women who had acquired knowledge on contraceptive methods after tubal sterilization (not in the table) had a significantly greater probability of requesting or undergoing tubal reversal (OR = 8.03, 95\%CI: 5.5-11.7).

Having had a deceased child, a partner with no children prior to the current union and a change in partner after tubal ligation increased the probability of reversal (Table 3).

The following risk factors associated with reversal remained statistically significant in the final multivariate model: age at time of interview, age at time of tubal ligation, decision-maker, time of tubal ligation procedure in relation to last childbirth, knowledge of contraceptive methods after tubal ligation, death of one or more children, partner with one or more children, and change of partner (Table 4).

\section{Discussion}

The aim of the present study was to understand the determinants of tubal reversal in northeastern Brazil.

Selection and recall bias are two problems in the interpretation of results from case-control studies. No women refused to participate in the study. This merits reflection as it is uncommon. The emotional aspects involved in the desire for a new pregnancy may explain such a situation. Good doctor-patient relationships at CISAM may also have contributed to the zero drop-out rate.

The double interview form (in person and by telephone) adopted by Wilcox et al. 18 was used here to obtain a sufficient number of cases in a short period of time. The use of two different forms for data collection did not influence the results, as findings were similar for the women who were interviewed in person and those interviewed over the phone 16 .

Characteristics of women who did or did not request or undergo tubal reversal at a public teaching hospital in relation to tubal ligation. Recife, Pernambuco State, Brazil, 1997.

\begin{tabular}{|c|c|c|c|c|c|}
\hline \multirow[t]{2}{*}{ Variables } & \multicolumn{2}{|c|}{ Tubal reversal } & \multicolumn{2}{|c|}{ No tubal reversal } & \multirow[t]{2}{*}{ OR $(95 \% \mathrm{Cl})$} \\
\hline & $\mathbf{n}$ & $\%$ & $\mathbf{n}$ & $\%$ & \\
\hline \multicolumn{6}{|l|}{ Age at tubal ligation (years) } \\
\hline $13-19$ & 58 & 19.3 & 13 & 4.7 & $59.49(21.3-165.7)$ \\
\hline $20-24$ & 166 & 55.1 & 67 & 24.3 & $33.03(13.7-79.4)$ \\
\hline $25-29$ & 71 & 23.6 & 116 & 42.0 & $8.16(3.4-19.7)$ \\
\hline$\geq 30$ & 6 & 2.0 & 80 & 29.0 & 1.00 \\
\hline$p$ value & & & & & $<0.0001$ \\
\hline \multicolumn{6}{|l|}{ Tubal ligation decision-maker } \\
\hline Herself & 81 & 26.9 & 206 & 74.6 & 1.00 \\
\hline Others & 220 & 73.1 & 70 & 25.4 & $7.99(5.5-11.6)$ \\
\hline p value & & & & & $<0.0001$ \\
\hline \multicolumn{6}{|l|}{ Time of tubal ligation } \\
\hline Trans-caesarean up to & 200 & 66.4 & 150 & 54.3 & $1.66(1.2-2.3)$ \\
\hline \multicolumn{6}{|l|}{45 days after childbirth } \\
\hline More than 45 days after childbirth & 101 & 33.6 & 126 & 45.7 & 1.00 \\
\hline $\mathrm{p}$ value & & & & & 0.003 \\
\hline \multicolumn{6}{|l|}{ Information from health professionals } \\
\hline \multicolumn{6}{|l|}{ on irreversibility } \\
\hline Yes & 105 & 34.9 & 200 & 72.5 & 1.00 \\
\hline No & 196 & 65.1 & 76 & 27.5 & $4.91(3.4-7.0)$ \\
\hline$p$ value & & & & & $<0.0001$ \\
\hline
\end{tabular}


Changes in family structure after tubal ligation in women who did or did not request or undergo tubal reversal at a public teaching hospital. Recife, Pernambuco State, Brazil, 1997.

\begin{tabular}{|c|c|c|c|c|c|}
\hline \multirow[t]{2}{*}{ Changes in family structure } & \multicolumn{2}{|c|}{ Tubal reversal } & \multicolumn{2}{|c|}{ No tubal reversal } & \multirow[t]{2}{*}{ OR $(95 \% \mathrm{Cl})$} \\
\hline & $\mathrm{n}$ & $\%$ & $n$ & $\%$ & \\
\hline \multicolumn{6}{|l|}{ Death of one or more children } \\
\hline No & 251 & 83.4 & 252 & 91.3 & 1.00 \\
\hline Yes & 50 & 16.6 & 24 & 8.7 & $2.09(1.2-3.5)$ \\
\hline$p$ value & & & & & 0.004 \\
\hline \multicolumn{6}{|c|}{ Partner with one or more children } \\
\hline No & 230 & 76.4 & 179 & 64.9 & $1.75(1.2-2.5)$ \\
\hline Yes & 71 & 23.6 & 97 & 35.1 & 1.00 \\
\hline$p$ value & & & & & 0.002 \\
\hline \multicolumn{6}{|l|}{ Partner change } \\
\hline No & 42 & 13.9 & 238 & 86.2 & 1.00 \\
\hline Yes & 259 & 86.1 & 38 & 13.8 & $38.62(24.1-62.0$ \\
\hline p value & & & & & $<0.0001$ \\
\hline
\end{tabular}

The final multivariate model of risk factors for regret after tubal ligation among women attending a public teaching hospital. Recife, Pernambuco State, Brazil, 1997.

\begin{tabular}{|c|c|c|c|}
\hline Variables & OR adjusted * & $95 \% \mathrm{Cl}$ & $p$ value \\
\hline \multicolumn{4}{|l|}{ Age at interview (years) } \\
\hline $20-29$ & 3.04 & $1.1-8.5$ & 0.06 \\
\hline $30-39$ & 4.03 & $1.2-14.0$ & \\
\hline $40-49$ & 1.00 & & \\
\hline \multicolumn{4}{|l|}{ Age at tubal ligation (years) } \\
\hline $13-19$ & 30.70 & $6.0-156.8$ & $<0.0001$ \\
\hline $20-24$ & 24.68 & $6.0-101.6$ & \\
\hline $25-29$ & 5.43 & $1.4-20.7$ & \\
\hline$\geq 30$ & 1.00 & & \\
\hline \multicolumn{4}{|l|}{ Tubal ligation decision-maker } \\
\hline Herself & 1.00 & & \\
\hline Others & 8.25 & $4.2-16.3$ & $<0.0001$ \\
\hline \multicolumn{4}{|l|}{ Time of tubal ligation } \\
\hline Trans-caesarean up to 45 days after childbirth & 4.19 & $2.0-8.8$ & 0.0001 \\
\hline More than 45 days after childbirth & 1.00 & & \\
\hline \multicolumn{4}{|l|}{ Contraceptive knowledge acquired after tubal ligation } \\
\hline No & 1.00 & & \\
\hline Yes & 3.89 & 2.0-7.6 & $<0.0001$ \\
\hline \multicolumn{4}{|l|}{ Death of one or more children } \\
\hline No & 1.00 & & \\
\hline Yes & 5.83 & $2.2-15.1$ & 0.0002 \\
\hline \multicolumn{4}{|l|}{ Partner with one or more children } \\
\hline No & 2.92 & $1.4-6.1$ & 0.003 \\
\hline Yes & 1.00 & & \\
\hline \multicolumn{4}{|l|}{ Change of partner } \\
\hline No & 1.00 & & \\
\hline Yes & 78.97 & 34.3-182.0 & $<0.0001$ \\
\hline
\end{tabular}

* OR adjusted for all variables in table. 
The fact that the control cases were asked if they had ever requested or intended to undergo tubal reversal (according to the subject's definition) did not bias the results, even though some women were only informed about reversal when they were approached to participate in the study. The inclusion of "cases to be" is considered an appropriate procedure in case-control studies 19 .

The very large proportion of results that were significant at or below the $0.1 \%$ level serves as a strong argument against a Type I error. One of the strengths of this study was the collection of information on a large number of variables that were likely to be associated to requesting or undergoing tubal reversal.

As with the results presented here, a number of studies have shown that there is a greater probability of requesting tubal reversal among women who were young at the time of surgery ${ }^{13}$. Hardy et al. ${ }^{1}$ reported that the risk of post-sterilization regret among women sterilized before the age of 25 was 18 times higher than among those sterilized after the age of 29. Younger women were also more likely to obtain reversals 13 , as younger women have a greater lifespan in which to change their lives, relationships and reproductive intentions.

Similar to results reported by Loaiza 7, the probability of requesting tubal reversal increased when surgery was decided by someone other than the woman herself. More than $73 \%$ of women who had requested or undergone tubal reversal were not the decision-maker responsible for the original surgery, including 17 women for whom sterilization took place without their knowledge or approval, when consent was given by their husbands or mothers.

Results related to the association between changes in family structure and the request for or submission to tubal ligation reversal were consistent with other studies 10,14,20,21. Hapugalle et al. 21 found that $92 \%$ of women who had requested reversal had lost children. The findings of the present study also showed a higher probability of requesting reversal among women whose partners had no children from previous unions. This was likely due to their partner's wish to have children, thereby giving rise to regret among the sterilized women. Similar to findings in the literature, the main reason for seeking tubal reversal was "the desire to give a child to her new partner" 7,10,12,20. The majority of women who requested or under- went tubal reversal had changed partners after ligation. Similarly, the present study found a new marriage to be one of the most important determinants of post-sterilization regret. Women who remarry often wish to become pregnant and have children with their new partners as a consolidation of the union 7,10,12,20.

In 1996, the Brazilian Congress approved a family planning law 22 that legitimized female and male sterilization as a reproductive right, thereby legalizing and regulating its practice. The law (no. 9,263) establishes that men and women can voluntarily request surgical sterilization provided they are at least 25 years of age or already have two children and that a minimum period of sixty days is observed between the time of request and the surgery. Furthermore, the law prohibits sterilization during childbirth, after an abortion or within 41 days of giving birth. The finding that there was a greater risk of regretting tubal ligation for women who had had surgery up to 45 days after childbirth was similar to that reported in other studies 21 and lends support to the Brazilian law forbidding tubal ligation associated with delivery, which was a long-standing practice in Brazil.

The association between sterilization regret and information regarding the irreversibility of the surgery was no longer statistically significant when adjusted for changes in partner after tubal ligation. It is possible that these women had only become aware of the irreversibility of the method after they chose to become pregnant following a change in partner. Furthermore, receiving information on contraceptive methods, even after undergoing tubal sterilization, increased the probability of requesting or undergoing tubal reversal. Reproductive choices involve sensitive and complex issues. In order for women to make such decisions, health services and professionals need to guarantee access to all contraceptive methods and information on their risks and benefits 23 . It is also necessary to understand women's psycho-socio-demographic profile and their reasons for requesting surgery. A conscientious approach to tubal ligation can contribute towards reducing the number of requests for reversal, which is a procedure that burdens public health services and has a high rate of non-success and complications including ectopic pregnancies 24,25,26,27. 


\section{Resumo}

Um estudo do tipo caso controle foi conduzido em um hospital público de ensino no Recife, Pernambuco, Brasil, em 1997, para investigar os fatores de risco para o arrependimento da realização da laqueadura tubária, comparando mulheres laqueadas que solicitaram ou realizaram a reversão da laqueadura tubária com mulheres também laqueadas que não solicitaram e não se submeteram a esta cirurgia. As mulheres que mostraram uma maior probabilidade de arrependimento foram as esterilizadas quando jovens, as que não foram responsáveis pela decisão da cirurgia, as que realizaram a esterilização até o 45o dia pós-parto $e$ as que adquiriram informações sobre métodos contraceptivos depois da laqueadura tubária. Morte de filhos, parceiros sem filhos anteriores à união atual e a mudança de parceiro após a laqueadura tubária também estiveram associados com a solicitação ou realização de reversão da laqueadura. Deve-se avaliar o perfil psicológico e sócio-demográfico das mulheres e seus motivos para solicitar a laqueadura tubária e aconselhá-las para o planejamento familiar a fim de reduzir os riscos de arrependimento futuro.

Reversão da Esterilização; Esterilização Tubária; Planejamento Familiar

\section{References}

1. Hardy E, Bahamondes L, Osis MJ, Costa RG, Faúndes A. Risk factors for tubal sterilization regret, detectable before surgery. Contraception 1996; 54:159-62.

2. Faúndes A, Costa RG, Pádua KS, Perdigão AM. Associação entre prevalência de laqueadura tubária e características sócio-demográficas de mulheres e seus companheiros no Estado de São Paulo. Cad Saúde Pública 1998; 14:49-57.

3. Berquó E, Cavenaghi S. Direitos reprodutivos de mulheres e homens face à nova legislação brasileira sobre esterilização voluntária. Cad Saúde Pública 2003; 19 Suppl 2:S441-53.

4. Potter JE, Perpétuo IHO, Berquó E, Hopkins K, Leal OF, Formiga MCC, et al. Frustrated demand for postpartum female sterilization in Brazil. Contraception 2003; 67:385-90.

5. Sociedade Civil Bem-Estar Familiar no Brasil. Pesquisa nacional sobre demografia e saúde. Rio de Janeiro: Sociedade Civil Bem-Estar Familiar no Brasil/Macro International Inc.; 1997.

6. Vieira EM, Badiani R, Dal Fabbro AL, Rodrigues Junior AL. Aspects of anticontraception methods used on São Paulo State, Brazil. Rev Saúde Pública 2002; 36:263-70.

\section{Contributors}

A. B. Ludermir was responsible for the statistical analysis and interpretation of results, and participated in drafting the manuscript. K. M. M. Machado participated in all phases of the study, including the original idea, design, data analysis and interpretation, and drafting of the manuscript. A. M. Costa participated in the choice of theme and collaborated in the interpretation of results and adjustments to the article. S. V. Alves collaborated in the interpretation of results and adjustments to the article. T. V. B. Araújo collaborated in the interpretation of results and adjustments to the article.
7. Loaiza E. Sterilization regret in the Dominican Republic: looking for quality-of-care issues. Stud Fam Plann 1995; 26:39-48.

8. Centers for Disease Control and Prevention. Tubal sterilization among women of reproductive age, update for 1979-1980. Atlanta: Centers for Disease Control and Prevention; 1983.

9. Rosenfeld BL, Taskin O, Kafkashli A, Rosenfeld ML Chuong CJ. Sequelae of postpartum sterilization. Arch Gynecol Obstet 1998; 261:183-7.

10. Hillis SD, Marchbanks PA, Tylor LR, Peterson HB. Higher hysterectomy risk for sterilized than nonsterilized women: findings from the U.S. Collaborative review of sterilization. The U.S. Collaborative Review of Sterilization Working Group. Obstet Gynecol 1998; 91:241-6.

11. Osis MJ, Faúndes A, Souza MH, Bailey P. Conseqüências do uso de métodos anticoncepcionais na vida das mulheres: o caso da laqueadura tubária. Cad Saúde Pública 1999; 15:521-32.

12. Nervo P, Bawin L, Foidart JM, Dubois M. Regret after tubal sterilization. J Gynecol Obstet Biol Reprod 2000; 29:485-91. 
13. Schmidt JE, Hillis SD, Marchbanks PA, Jeng G, Peterson HB. Requesting information about and obtaining reversal after tubal sterilization: findings from the U.S. collaborative review of sterilization. Fertil Steril 2000; 74:892-8.

14. Kim JD, Kim KS, Doo JK, Rhyeu CH. A report on 387 cases of microsurgical tubal reversal. Fertil Steril 1997; 68:875-80.

15. Kim SH, Shin CJ, Kim JG, Moon SY, Lee JY, Chang YS. Microsurgical reversal of tubal sterilization: a report on 1,118 cases. Fertil Steril 1997; 68:865-70.

16. Machado KMM, Ludermir AB, Costa AM. Changes in family structure and regret following tubal sterilization. Cad Saúde Pública 2005; 21:1768-77.

17. Kleinbaum DG. Logistic regression: a self-learning text. New York: Springer Verlag; 1994.

18. Wilcox LS, Chu SY, Eaker ED, Zeger SL, Peterson HB. Risk factors for regret after tubal sterilization: 5 years of follow-up in a prospective study. Fertil Steril 1992; 55:927-33.

19. Breslow NE, Day NE. Statistical methods in cancer research. Lyon: International Agency for Research on Cancer; 1980.

20. Hillis SD, Marchbanks PA, Tylor LR, Peterson HB. Post-sterilization regret: findings from the U.S. collaborative review of sterilization. Obstet Gynecol 1999; 93:889-95.
21. Hapugalle D, Janowitz B, Weir S, Covington DL, Wilkens L, Aluvihare C. Sterilization regret in Sri Lanka: a retrospective study. Int Fam Plan Perspect 1989; 15:22-8.

22. Brasil. Lei ordinária no. 9.263, de 12 de janeiro de 1996. Diário Oficial da União 1997; 24 nov.

23. Barbosa MR, Knauth DR. Esterilização feminina, AIDS e cultura médica: os casos de São Paulo e Porto Alegre, Brasil. Cad Saúde Pública 2003; 19 Suppl 2:S365-76.

24. Vieira EM. O arrependimento após a esterilização feminina. Cad Saúde Pública 1998; 14 Suppl 1: 59-68.

25. Cantor R, Riggal FC. The choice of sterilization procedure according to its potential reversibility with microsurgery. Fertil Steril 1979; 31:9-12.

26. Cunha GB, Macedo G, Silva PRG, Florêncio RS, Alencastro JB. Tubal reanastomosis by videolaparoscopy after surgical sterilization. Initial results. Rev Bras Ginecol Obstet 1998; 20:105-9.

27. Carvalho LEC, Cecatti JG, Osis MJD, Sousa MH. Ideal number of children and regret after tubal ligation in a cohort of women. Rev Assoc Méd Bras 2006; 52:293-7.

Submitted on $21 /$ Nov/2007

Final version resubmitted on 14/Aug/2008

Approved on 29/Aug/2008 